\title{
SOCIAL WORKER'S HELP IN RESTORING HUMAN DIGNITY
}

\section{VIRBALIENE் Akvilè}

Klaipèda State University of Applied Sciences, Klaipèda, Lithuania

\begin{abstract}
In this article are presented situations in which the feeling of dignity of a person is lost or decreases and cannot be restored without professional intervention. This loss is one of the reasons of social exclusion in communities. A person with social issues has no abilities to emphasize her/his own uniqueness and authenticity, s/he stops to progress physically, intellectually and spiritually. In this way these persons enter the field of social worker's help. In this field of help, one of the main factors in the restoration of human dignity is the social worker her/himself: her/his personality can have a huge influence on his client. The main research question in this study is the following: How should a social worker construct the helping process to help the client to restore her/his human dignity? Research object was the social worker's help in the process of the restoration of human dignity. Research aim was to reveal the elements of the social worker's support process that help to restore human dignity. Analysis of the reseach-based conceptual literature was the core method to explore and reveal the answers to research questions. The findings of the analysis highlighted that in situations, when people loose their feeling of dignity within social exclusion then they experience the self-deprecating. In the process of social help a main role is played by social worker's professional communication with the client: the social worker stimulates the maintenance and restoration of client's dignity by applying the principle of acting together. This principle is based on moral values, reciprocal responsibility, mutual respect, sincerity, confidentiality and empathy. These components create a trustful environment where, by sustaining client's free choice and a right of decision, the possibility to achieve client's openness emerges.
\end{abstract}

Keywords: Confidentiality; Empathy; Human Dignity; Social Exclusion; Subsidiarity.

\section{Background}

Human dignity is not just a preoccupation of every individual separately. Persons in our contemporary life usually have difficulties to maintain the dignity only with their own efforts. On the contrary, the dignity is maintained through a reciprocal dialogue and acceptance of every human's immunity. Without the community and relationships with other people and relational network the person is not able to state neither the individuality of others, neither her/his own individuality. Hence, dignity is a communal value. In other words, a person with dignity consists not only from the aspects that one should defend, sometimes desperately, on her/his own efforts (Bauman \& Donskis, 2013). The main purpose of every person is to understand her/his own essence and maintain the dignity in interpersonal relations with the aim to be recognized and respected (Virbalienė \& Žydžiūnaitè, 2010). But the socially affected persons confront the issue of their personal worth in another way as well. If one finds her/himself socially excluded and did not 
make the right problem solutions on time, it becomes more difficult to understand her/his own worth and that $\mathrm{s} / \mathrm{he}$ is needed in the society. By renouncing the moral and behaviour norms, they also reject their dignity and lose their personal worth, while they do not feel conscious responsibility for their behaviour. In this case, any crisis in life is solved in the material level, not in the moral nor spiritual sphere.

Human dignity is necessary for one's existence. If it is destroyed, one finds it difficult to feel the existential meaning. This notion of meaning is the main existential question in general and the destruction of meaning conducts to the end of one's existence (Kavaliauskienè, 2008). No one is able to outlast a life with no meaning due to the fact that the meaning itself is an axis of the existence, which focuses everything around itself. When the meaning disappears, a subject feels like losing himself, becomes depressed, is not able to feel her/his own worth and his existence seems to him as something miserable. These are the reasons why these persons enter the field of social worker's care. It seems from the first sight that the social work nowadays has enough experience in the helping process, but the number of clients is abundantly growing and the social problems are getting deeper meanwhile in the practice of social work the attention towards the human dignity is insufficient. In this system of helping, the social worker can be understood as the main instrument: s/he can offer his help professionally without depreciating one's dignity; on the contrary, one of her/his objectives is to maintain the dignity or to restore it. These objectives can be accomplished just when the person understands correctly the notion of being a person. Why is every person worthy? Precisely the social worker has the competence to speak about it. Her/his activity becomes meaningful and significant just when s/he appreciates every person's worth and this helps in the creation of reciprocal relation of trust. This relation helps in solving the problems and restoring the meaning of life with its worth and dignity. The human dignity is an axiom of every person's life quality (The Principle of Respect for Human Dignity: European Commission for Democracy through Law, 1998). The human dignity is as well a base for the system of human rights. Hence, a very big responsibility falls on the social worker in her/his work with a person who has to deal with this issue: the worker has to help her/him to solve material and moral problems without downgrading his dignity and by supporting her/him.

In the researches of Lithuanian scholars, the human dignity is more frequently analysed from the Law, theology, education and philosophical assumptions. Peičius (2000), Jovaiša (2001), Meškauskienè (2002, 2005), Vaišvila (2004, 2005), Venckienè (2005, 2008), Mockus (2006), Virbalienè (2006), Kairienė (2010), Virbalienė \& Žydžiūnaitė (2010), and foreign researchers such as Lobato (2001), Chaskalson (2002), Dicke (2002), Meyer (2002) and Donnelly (2009) state the complexity of human dignity as a phenomenon in their researches. The notion of dignity in social work studies is similar to its perception in law studies. In the practice of social work, it is more frequent to write about the factors of human dignity maintenance from the perspective of gerontology (see, for example, Lothian \& Philip, 2001; Brestovansky, 2005; Dwyer, 2008; Hall et al., 2009). There are studies, which are focused on the questions of the dignity's maintenance when working with disabled persons (Vorhaus, 2015). Nevertheless, there are no extensive studies that would be directed exceptionally to the restoration of human dignity of persons in groups of social risk while working 
with a social worker in the helping process; all we have are the declarations of the principles that one should follow while working with socially affected persons. However, it cannot be dened the fact that the restoration of dignity of a person in a risk group who has entered the field of social worker's help is one of the main aspects that lead to a successful solution of the issue or problems. Equally, it helps the person to accomplish his integration back to the society by feeling her/his worth and respect of others. The research question it is raised in this research is the following: How should a social worker construct the helping process to help the client to restore his human dignity? Research object was the social worker's help in the process of the restoration of human dignity. Research aim was to reveal what are the elements of the social worker's support process that help to restore human dignity.

\section{The person in social exclusion - insecure member of the society}

The $21^{\text {st }}$ century is a period when our attention to a human being and her/his worth is distracted by other factors. A person's worth is a specific power or ability to accomplish hre/his aims; this skill is usually called worthiness (Hobbes, 1999). Hobbes considers that the dignity itself is not worthiness, but it results from worthiness. Thus, a person's worthiness is a natural skill to accomplish her/his duties that are meaningful for the society in an appropriate way. By fulfilling her/his duties and giving sense to his activities, a person starts to feel his worth and understands her/himself as a dignified member of the society (Lobato, 2001; Statman, 2002; Donnelly, 2009; Virbalienė \& Žydžiūnaitè, 2010). Researchers speak about different crisis of values that have a negative impact on one's feeling of dignity. Despite of that, today the biggest crisis of values is caused by the impossibility to understand one's own worth (Venckienè, 2008). Due to that, dignity as person's worthiness derives from a person's ability to live properly in a society. It is yet difficult to define the concept of living properly in a postmodern society as the postmodern world had transformed subject's identity to an object of consumption. Therefore, if one wants to become an active unit in today's society, s/he is obliged to consume (Bauman, 2007). Having this in mind we see that the lowest class had become worthless in a postmodern society: the members of this class are not capable of creating the added value and so they are not included in the circles of investments and marketplaces. The mentioned above reasons influence the situation that the members of higher social classes are more appreciated (Baudrillard, 2010, Bauman, 2007). Thus, this rapid change in social life and a gap between social classes influenced the formation of social exclusion. Furthermore, in our societies we confront with an unequal repartition of power and wealth that is created by the system itself, as well as with intolerance towards different people: this also creates a favourable medium for social exclusion (Mikulionienè, 2005). In different societies we always find the injured that are alienated as aliens and the shattered. Those who could not persist with the majority of the society for divergent reasons find their place in the lower position of the pyramid and constitute the lowest class of marginal minorities and outcasts (Urmoniene, 2005). So the social tension in the society creates the conditions for the appearance of marginal groups and the rise of anomie, deviation, delinquency, social 
arrhythmia (a dissolution of interaction and activities between the administration and other links of social and political organization), social apathy, social fatigue and excessive social differentiation that leads to social conflicts (Grigas, 2001).

In the course of state's instability and considering the changes in social structure, an increased number of persons find themselves outside the social life's limits. This class is growing all the time and is a cause of society's disorganization, which stimulates the social, psychological and usually a complete isolation of one group of persons. Persons, who find themselves in a difficult situation are forsaken by other members of the society, and their social requirements (of recognition, self-expression and security) are not fulfilled. If one has no opportunity to choose her/his virtues due to a lack of resources, various reactions can emerge: a conformance with the situation (as consequences of that we can mention alcoholism, drug addictions, prostitution); a beginning of some different, strange activity (usually one tries to reach his aims in illegal ways); a refusal of any purposes, a departure (e. g. one starts living as homeless); a resistance (one consciously tries to make changes in the structure) (Urmonienè, 2002). All these circumstances are risky factors with respect to one's dignity and loss of personal worthiness: in consequence, a person feels insecure in the society, while the protection of human dignity provides the feeling of trust in personal relations which is very important in the creation of state's welfare and society's security (Venckiene, 2008). For example, individual security is more powerful and influential in the pyramid of needs than, e.g., love. Therefore, the feeling of insecurity causes social exclusion. If one does not feel his worth, it is difficult to maintain his dignity and defend it.

European Commission (1998) proposed the definition of the social exclusion of a person. It includes not only the present situation of exclusion but pays attention to the processes that expel the subjects from the society. In this definition it is concluded that every society has a number of citizens that are excluded from the economic and social life and from their part in the common welfare. These persons cannot use their social rights without outside help, they suffer from a lack of self-respect, their skills do not correspond with their duties (commitments), they have to bear a permanent downgrade for being socially endowed and, because of that, dishonourable. In this case, the social exclusion means filling the margins of the society. This leads to various restrictions of his freedom of choice, fear of the future and humiliation of one's dignity. Researches (Littlewood, 1999; Taljūnaitè, 2004; Mikulionienè, 2005) affirm that those who can be characterized by their weak physical of psychical health, bad economic situation or whose families are insecure, tend more to enter the risk of social exclusion. From the perspective of human rights, dignity is defined as a necessity to fulfil one's own duties and create an individualized, that is, meaningful social life. This self-fashioning implies that a subject's meaningful worthiness rise from his capability to live properly under the values that are practiced in a particular society (Vaišvila, 2005). When persons are included in these groups of risk, they become inactive culturally, cannot create their own social worthiness, that is, cannot be helpful to others and guarantee their suitability to live in a dynamic society. This suitability lifts special requirements that this person cannot establish nor change; all s/he can is to adapt her/himself to the 
norms and in this way prove his suitability. This means that fulfilling her/his duties and creating a meaningful welfare for the society a person at the same time creates her/his social worthiness, feels her/his own worth from his own perspective and from the perspective of the others. The rest of the members of the society appreciate the ability to be useful, cooperate, create the welfare and participate in equivalent interchange, as well as to live peacefully with other members of the community. As follows, socially excluded persons or those who have social problems usually feel a derogation of their dignity because they are unable to fulfil their duties and participate in the relations of interchange. The rights of this person are often destroyed and lessened. In this manner the human dignity in the context of solving social problems becomes the object of law, because the right to human dignity is absolute and cannot be lost as it does not depend on person's behaviour that does not correspond with social norms and requirements. The subject of law itself is humanness in its own physical and spiritual integrity, so it cannot be lost, but can be violated (Venckienè, 2008; Kairienè, 2010). The law defends human dignity from oppression and harm and at the same time frees it and helps one to feel her/his own worth.

Persons who live in social exclusion and confront social issues feel a violation of their human dignity while living in a society. From the moral perspective, it is more difficult for these persons to feel the meaning of their worthiness and for them it is troublesome to create values. These persons are stroked by anger because they feel no respect for their dignity. The acceptance of human dignity's worthiness is a necessity. The tension in the community appears when the society alienates and often even discriminates these persons. They need help that would be based on a structure of values and would concentrate one's own powers to help her/himself and restore human dignity, which was downgraded due to an unsolved social problem.

Persons who live in social exclusion, due to their inability to participate in society's life, become the most insecure members of the society and cannot give meaning to their activities, alienate themselves from social and economic values, and lose their material resources, and abilities to interact in common social situations. A person in a social exclusion is not recognized as a competent member of this society, so the worthiness of this person is questioned by discrimination and her/his dignity becomes downgraded.

\section{Maintenance of Clients' Dignity in the Practice of Social Work}

The person is a central axis in the process of social work. A person, who becomes a client of the social worker, is unique and her/his life history is unrepeatable. When a competent social worker affiliates a relationship with her/his client, s/he knows that her/his personality is violated, so they (the social worker and the client) together have to try to restore a mutual beneficiary interaction between the person and the society. A social worker can accomplish this purpose just if her/his activity is conducted by highest values. In the activities of a social worker, who is creating a help-based relationship with the client aims to reach the personal respect for a person and her/his dignity. The social worker first of all must to stimulate the violated person to start to be self-confident, feel her/his own worth because of being a human and / or person. When 
working with their clients the social workers have to believe in innate human worth and dignity (Johnson, 2001). Therefore, in the creation of the help-based relationships with a client a social worker has to rely on the value of respect, and it is a base while trying to reach a closer relationship that would be based on mutual trust. The social worker has to motivate changes from client's perspective when s/he is trying to recreate the client's social interactions. This skill is particularly important in social worker's activities because this perspective can recall a person's feeling to be needed and valuable. Anyhow, the social worker should not intend to reach the person's fulfilment of society's requirements, but an increment in one's personality, raised from the social interaction, and an overcasting of various psychosocial problems (Jurkuviene \& Snieškienè, 2008). This aim is primarily reached if the social worker is able to create interpersonal relations between the client and the social worker, which is a necessary component in the helping process. These relations are a conjunctive link, it is a product of the interaction of two persons (Šatkauskienè, 2014). The relationship between the client and the social worker is defined as "spirit" ("heart") and the social worker is the main agent who implies the intervention within the social work (Farrahas, 2012).

The main aim in achieving the goals of social worker is to base his relationship with clients on values so $\mathrm{s} / \mathrm{he}$ could again feel his worth and that $\mathrm{s} / \mathrm{he}$ is needed and useful for the society. In the social work the following moral principles are of most importance: humaneness, love, empathy, equality, tolerance, respect, courage, honour and honesty. The links between these values constitute the content of dignity, they are its basic components (Virbalienè \& Žydžiūnaitè, 2010). Thus if a social worker follows these values while working with a client, it is easier for him to feel her/his worth and restore her/his dignity. No other specialist has so many close links with person's destiny as a social worker (Prakapas, 2007). So the social worker attains a big responsibility to help a person to restore her/his meaningful interaction with a society and to restore his suitability in the community. Hence, if a social worker's goal is to help to restore the violated feeling of dignity, her/his success depends on his ability to follow the values while creating a reciprocal relationship. Theoretically this goal is not difficult to reach because it is everyone's duty to respect others and their dignity in spite of the activity nor choices of values, as every person is valuable unreservedly and should be respected and valued just as s/he is.

The social worker in the helping process encounters her/himself with the challenge to help a person to primarily restore her/his worthiness, which would let her/him to solve her/his problems and not, conversely, resign and live with them. Yet the social work actually still impresses with its aspirations more than with concrete and tangible achievements or prestige (Kavaliauskiené, 2005). The objective of a social worker is noble, but often he confronts himself with unsolvable tasks. This situation raises because of the twofold orientation of social work: on one hand, it is directed towards a person, but on the other hand, to the society; that is, the direction goes towards a whole and towards its part - the community and the individual - by trying to reach their interaction and consistency. This mutual consistency can be restored only during the process of reciprocal interaction. The violated members of the society usually oppose the moral conduct, refuse the restoration of their social worthiness (by completing their duties, pursuing their generous 
objectives) and adapt themselves to live with the downgraded feeling of dignity. Every social worker who is willing to help engages himself to be near the oppressed and rejected persons and communities (Healy, 2001). The followers of critical social work emphasize that the consciousness of these outcasts that are oppressed is erroneous while they understand the nature of community's order inadequately. In consequence, these persons do not understand the importance of their worth, do not maintain their dignity and adapt to the situation of violation and consider it as a consequence of their own activity. The main task of a social worker becomes the fight against erroneous beliefs and the promotion of understanding of one's proper skills and abilities to interact rationally and consciously (Šatkauskienè, 2014). The social work should be based on the values of equality, social wellfare, democracy, human rights, cooperation, mutual dependence and social fairness, and then it can help and stimulate the integration of an excluded person to a society and the restoration of her/his worth and necessity in the society. The social inequality and its consequences are the main causes in violation of human dignity, so social workers are engaged to seek social justice as this value is one of the main values in the practice of social work (Grayet et al., 2012). When the social workers seek social justice, they acquire trust from their clients and this stimulates the change of the persons who have suffered.

Further, the principle of subsidiarity should be applied in the social work practices with the most affected members of the society. The central aspect of subsidiarity is the recognition of human dignity and every subject's indisputable worthiness. Having this in mind, a social worker should consider her/his client as a human being in his totality (Petružytė et al., 2004). If one follows this principle, s/he does not affect the dignity in the helping process; when the dignity is already affected or violated, s/he helps to restore it. Every individual feels a necessity for fulfilment and happiness - these are the main aspirations; all the rest of necessities are circumstanced by this aspiration (Vittadini, 1997). It is possible to follow the principle of subsidiarity just if a mutual link of trust is developed between the client and the social worker. This trust proceeds from reciprocal respect and the ability to recognize each other's worth (Petružyte et al., 2004). Thus, in the helping process the client is understood as a human being, her/his worthiness and dignity are recognized, stressing as well the importance of her/his own decisions in solving his problems. From this point of view, it is essential to recognize the client's own capacity to solve or help to solve his problems, while the social worker has to notice and evaluate her/his competences and abilities to solve these issues. In this manner, the social worker avoids the exhibition of his power and authority in the helping process and the relationship between the worker and the clients is more of cooperation where the client is treated as an equal partner. This notion stimulates the mutual apprenticeship of solving problems as long as every person is unique and can have different abilities of solving problems. So the main assumption of subsidiarity is that the social worker is learning from his client and vice versa. By doing so, they concentrate mutual powers to solve the problem and reach a shared aim. During this process the client naturally starts to feel her/his worthiness and acknowledges his dignity. By following this principle of cooperation and mutual help the social worker achieves the maintenance of client's dignity. 
The power and power relations are always connected with social work because the notion of help encompasses both power and dependence: if someone needs help, s/he is weaker and dependent, and the other part can (has the power) to ensure this help, that is, he has resources, capacities or, finally, wish and motive to help (Švedaitè et al., 2014). So it is especially important to base the work on principles of respect because these relations concern power. The choice of communication model without a single-sided authority is essential, and the principle of "I can and you can't" has to be forgotten. Generally in social work the power should be considered as empowerment, that is, the division of individual strength that at same time stimulates the experience fellowship in the society (Jurkuvienè et al., 2014). If the social worker does not understand correctly the meaning of power, he can accidentally corrupt the essence of social work. Then the main risk is that in the helping process the social worker becomes a controlling ruler who demonstrates her/his power and obliges her/his problematic client to feel powerless; and, in this manner, s/he can completely break her/his dignity, which is already downgraded. This unprofessional behaviour means that there is a possibility to lead to the loss of meaning and violation of human dignity instead of making one's life meaningful. Basing the relationship of the social worker and his client on power principles, formal communication and strict following of rules predominate (Jurkuvienè et al., 2014). These relations that are based on power and force usually influence the indications of human dignity humiliation. When the links between social worker and client are strictly formal and are ruled by juridical legislation, the so called "impact means" are underlined and there is no space for creating a relationship of trust and maintaining human dignity. All in all, during the helping process the social worker needs to clearly understand the content of the notion of power and provide his help considering the essential principle: to believe in human's natural worth and dignity (Johnson, 2001). So while trying to maintain the human dignity during the helping process the principles of human rights and social justice are essential. The base is social worker's ability to respect client's decisions in solving problems and his capacity to stimulate the use of his right to help; these factors permit the client's feeling of worth and her/his necessity in the society.

The principles that let to maintain and preserve the dignity in the practice of social work are the following: defence of human rights, security of confidentiality and respect. It is not sufficient if the social worker apprehends that the person himself and his dignity are the main values. It is indispensable to engage to stimulate the security of human dignity and its maintenance. Correspondingly, the professional work of a social worker, his trust in the client and the appreciation of his efforts in the helping process can lead to a better quality of her/his life.

There is a guideline of seven main components that should be taken into account in the social work practices and applying these directives a social worker maintains the human dignity of his client. Those directives are the following: mutual consulting, acceptance, a right to make decisions, a right of choice, confidentiality, empathy and sincerity (Gordon, 2000). Consulting embodies more than just giving information and discussing it. According to Butkevičienè (2010), this "more" means that people communicate basing their interaction on arrangements, they arrange their purposes and the structure of roles. 
This kind of interaction is founded on the respect for human dignity and belief that every human being has internal opportunities to reveal and express himself; the main labour is to create the conditions to fulfil it. Wherefore in the process of mutual consulting the social worker gives the opportunity for growth, development and final understanding of the behaviour, apprehension of one's essence, feeling of one's worth. The client is permitted to feel the master of her/his own life where s/he can function without violating the rights of other persons. During the mutual consulting the necessities of security, dependence, and selfevaluation are fulfilled so the clients start feeling needed and appreciated by maintaining their human dignity in this way.

The principle of acceptance signifies that the social worker offers her/his help and accepts every client and appreciating her/his worth despite her/his material situation, status, religion, race or behaviour. It stimulates the self-respect of every client. When the social worker creates an opportunity to actively involve the client in solving problems, s/he stimulates his feeling of worth and self-respect. A congruent specialist who shows an unconditional respect and emphatic understanding is a very important condition during the helping process while trying to maintain the client's dignity and stimulate her/his change and development (Corsini \& Wedding, 2011). Congruence is the authenticity, sureness and sincerity of the social worker. The exterior expressions of the specialist have to correspond to her/his internal experience (Paplauskaite et al., 2014). This means that if a social worker wants to maintain the client's dignity, s/he has to be faithful to her/himself and do not be hypocrite because only the sureness and the sincerity of the social worker help in the change and growth of her/his client. Unconditional acceptance of the client and respect towards her/him condition a relation that is not judging, free from evaluation; this respect allows client's natural feeling of his worth and necessity while restoring her/his dignity. The more due to it the social worker is, more possibilities for a change appear. Rogers (2005) noticed that almost in every sphere of our lives we are influenced by external evaluations with punishments and encouragements: "It is good. It is rubbish. You deserve the highest grade. I understand that I make these judgements too often, just as everyone else does. But I have experienced that these judgements do not stimulate personal growth, so I do not believe that they could form part of a helping relationship" (Rogers, 2005, p. 57). All this means that if one wants to help her/his client, s/he has to unconditionally accept him.

When speaking about the principle of the right to make decisions, we mean that the social worker should stimulate her/his client to help himself by creating opportunities to get more confident and take the responsibility for her/his own problems (Gordon, 2000). A social worker who respects her/his client's right to make decisions, respects her/his dignity at the same time. Working professionally s/he lets the client to decide himself about his abilities to solve problems. The client has the right to decide and it must be a recognized right to make free choices and decisions during the helping process (Kavaliauskiené, 2001). Johnson (2001) states that this right of making decisions is not only a right to decide, it is also a right to experience the consequences of these choices. Hence, this principle may cause problems to the social worker as a dilemma of trust emerges. Additionally, this right of freely making decisions could be limited by clients' 
ability to make positive and constructive decisions due to the civil and moral laws and the established functions of the institution.

The principle that is called a right of choice helps the social worker to maintain her/his client's dignity. This means that the client has a right to freely choose and reflect on her/his choices and what influence do her/his choices have on others. We could identify one's freedom with responsibility (Šliogeris, 2011). In the helping process the social worker ensures the freedom of choosing and making decisions responsibly, that is, a possibility to react unforced in the process of problem solving is conceded. This possibility to choose could be understood as a measure to express respect to person's worth and dignity. The client exhibits her/his freedom of choice while solving her/his problems in an interaction with the social worker. Still, the social worker has to be responsible for her/his client and his choices. This social worker's responsibility is based on individualization: the social worker recognizes her/his client as unique, recognizes her/his worth and maintains her/his dignity (Šatkauskienè, 2014).

Following the principle of confidentiality we ensure the maintenance of client's dignity. Although confidentiality is based on trust, the social workers sometimes confront themselves with obstacles in securing confidentiality. At the same time, obstacles on maintaining human dignity appear. One of the obstacles in ensuring the confidential relationship are the personal characteristics of the social worker (Kavaliauskiené, 2010). For example, the social worker sometimes does not have trust in his client: this causes a reduction in his self-esteem and as well violates his dignity. So the boundary between confidentiality and client's welfare is of most importance, because the welfare could not be reached when there is no trust in the relationship. If someone transgresses the principle of confidentiality, this should mean that one has no ability to feel empathy for her/his client, has a lack of respect and cannot recognize the human dignity of her/his client.

Empathy is the feeling or imagining the emotional experience of the other person (McDonald \& Messinger, 2011), which allows the understanding of the thoughts, feelings and actions of the other person and react to her/his experiences. This feeling helps to maintain client's dignity as $s / h e$ feels understood, s/he can understand her/himself and feels her/his worthiness, so this is the main factor for client's progress. The essential aspect of empathy is the ability to feel and fixate accurately what is the other person experiencing not only from her/his words, but also from her/his nonverbal language. Thus, a social worker, who has the ability to react with empathy and understands her/his advantages and disadvantages: if you accept yourself just as you are, you will be able to accept others as well (Gordon, 2000). In such way, through the emotional reaction to client's experience, social worker maintains the client's dignity. Nevertheless, the communicative aspect of empathy is also significant because the degree to which the social worker is able to convince his client is crucial. Empathy can only appear in a relation that is sensitive, where the client can express himself and hear her/himself and then feel her/his necessity and her/his own strength in solving problems.

The sincerity of the social worker is one of the main attributes while trying to maintain the client's dignity. The sincerity of the social worker helps her/his client to become what s/he wants to be (Vaicekauskiene, 2003). A sincere social worker by definition is the one that works separately with every client, does not 
apply the same methods to different cases and is flexible in the helping process. This aspect of sincerity helps to avoid the position of defence and the social worker becomes open to her/his client. When the client notices that, he opens her/himself as well and positive changes in the helping process can be noticed.

\section{Conclusions}

Persons who are socially excluded or who have social problems experience intensively the social tension and all its consequences: puberty, addictions, losses, physical and psychical illnesses. In a sudden social change a person loses her/his feeling of worthiness and her/his dignity is violated or downgraded. A person with social problems cannot spotlight her/his uniqueness and oneness, s/he stops her/his physical, intellectual and spiritual development, loses her/his feeling of security and considers her/himself as an unnecessary member of the society. The society usually has a negative, lowering and intolerant point of view towards a person in social exclusion, so the person starts living marginal life and cannot accomplish her/his duties and be socially worth: this situation downgrades her/his dignity. Human dignity as an absolute value should not be treated with reserve, although in the field of social problems the possibility of violation of human dignity emerges.

The work of social worker is meaningful because s/he has the power to help. In this practice the main factor is the social worker her/himself while her/his efforts and generosity influence the clients' will to reintegrate to the society, feel their worthiness and restore the human dignity. The social worker creates a helpful relationship where the essential component is the social worker her/himself and her/his professional activity; after creating this relationship, s/he can restore the client's dignity. The human dignity is maintained and restored by following the principle of cooperation that is based on moral values, mutual preoccupation, reciprocal respect, sincerity, confidentiality and empathy. If one fulfils these requirements, trust and the opportunity to open oneself is created, but the rights of decision and choice are sustained. The social worker's professional work, creativity and the principle of subsidiarity permit the creation of helping techniques that help in consulting: it causes the strengthening of the self-confidence and responsibility.

\section{References}

Baudrillard, J. (2010). Vartotoju visuomene: mitai ir struktūros. Kaunas: Kitos knygos.

Bauman, Z. (2007). Globalizacija: pasekmès žmogui. Vilnius: Apostrofa.

Bauman, Z., \& Donskis, L. (2013). Moral Blindness: the Loss of Sensitivity in Liquid Modernity. Cambridge: Polity Press.

Brestovansky, L. K. (2005). Privacy \& Dignity Issues in Nursing Homes. NY: Springer.

Chaskalson, A. (2002). Human Dignity As a Constitutional Value. The Concept of Human Dignity in Human Rights Discourse. Hague: Kluwer Law International.

Corsini, R. J., \& Wedding D. (2011). Šiuolaikine psichoterapija. Kaunas: Informatika ir poligrafija. 
Dicke, K. (2002). The Founding Function of Human Dignity in the Universal Declaration of Human Rights. The Concept of Human Dignity in Human Rights Discourse. Hague: Kluwer Law International.

Dirgèlienè, J. (2010). Konfidencialumo išsaugojimo trukdžiai socialinio darbo procese. Acta Pedagogica Vilnensia, 24, $32-42$.

Donnelly, J. (2009). Human Dignity and Human Right. Denver: University of Denver.

Dwyer, L. L. (2008). Dignity in the End of Life Care: What Does It Mean to Older People and Staff in Nursing Homes? Doctoral Dissertation. Sweden: Örebro University.

Gordon, W. (2000). Social Work. Switzerlan: UNESCO.

Gray, M., Midgley, J., \& Webb, S. (2012). The SAGE Handbook of Social Work. London: Sage Publications.

Grigas, R. (2001). Tautine savivoka. Vilnius: Rosma.

Hall, S., Longhurst, S., \& Higginson, I. (2009). Living and Dying With Dignity: a Qualitative Study of the Views of Older People in Nursing Homes. Age and Ageing, 38, 411-416.

Harnwell, B. (2008). Visuotine žmogaus orumo deklaracija. Available at http://www3.1rs.lt/docs2/ZVTJHYAI.DOC (Retrieved on $06 / 05 / 2015$ )

Healy, K. (2001). Reinventing Critical Social Work: Challenges from Practice, Context and Postmodernism. Crtical Social Work, 2(1), 201-238.

Hobbes, T. (1999). Leviatanas. Vilnius: Pradai.

Johnson L.C. (2001). Socialinio darbo praktika. Bendrasis požiūris. Vilnius: VU Specialiosios psichologijos laboratorija.

Jovaiša, L. (2001). Ugdymo mokslas ir praktika. Analitinių straipsnių monografija. Vilnius: Agora.

Jurkuvienė, R., Gajdosikienė, I., \& Jokubauskè, S. (2014). Jègos ir galios diferenciacija lietuviškajame socialiniame darbe su socialinès rizikos šeimomis. Socialinè teorija, empirija, politika ir praktika, 10, 7-20.

Jurkuvienè, R., \& Snieškienè, D. (2008). Socialinè raida. Kaunas: Vitae Litera.

Kairienè, B. (2010). Orumo kategorija bausmès koncepcijoje. Logos, 65, 144-153.

Kavaliauskienè, V. (2005). Socialinio darbo, kaip pagalbos žmogui profesijos, raidos aspektai. Acta Pedagogica Vilnensia, 15, 230-239.

Kavaliauskienė, V. (2008). Socialinio darbuotojo asmenybės savybės - santykio su profesija išraiška. SOTER, 26, 86102.

Littlewood, P. (1999). Social Exclusion in Europe: Problems and Paradigms. Aldershot: Ashgate.

Lothian, K., \& Philp, I. (2001). Maintaining the Dignity and Autonomy of Older People in the Healthcare Setting. British Medical Journal, 322, 668-670.

McDonald, N., \& Messinger, D. (2011). The Development of Empathy: How, When, and Why. In: Acerbi, A., Lombo, J. A., Sanguineti, J. J. Free will, Emotions, and Moral Actions: Philosophy and Neuroscience in Dialogue. London: IF-Press.

Meyer, M. (2002). Dignity as a Modern Virtue. The Concept of Human Dignity in Human Rights Discourse. Hague: Kluwer Law International.

Meškauskaitè, A. (2005). Orumo sampratos ir orumo apsaugos bei ugdymo ypatumai demokratinëje visuomenèje. LOGOS, 44, 152-157.

Meškauskienė, A. (2002). Svarbesni asmenybės orumo ugdymo bei apsaugos aspektai. Pedagogika, 62, $13-17$. 
Mikulionienė, S. (2005). Socialinè atskirtis: sąvokos samprata ir vartosena Lietuvoje. Socialinis darbas, 4(2), 20-32. Mockus, K. (2006). Žmogaus orumo ugdymas: filosofinė, psichologinè ir pedagoginè interpretacija. Tiltai, 4, 49-58. Paplauskaitė, E., Pladas, J., \& Petružytė, D (2014). Kontakto su šunimis panaudojimas vykstant socialinės pagalbos procesu. Socialinis darbas. Patirtis ir metodai, 13(1).

Peičius, E. (2000). Žmogaus orumo koncepcija kaip autonomijos reikalavimai. Humanistica, 3(9), 15-22.

Petružytė, D., Girdzijauskienè, S., \& Gvaldaitè, S. (2004). Subsidiarumo principas socialiniam darbuotojui sąveikaujant su klientais. Socialinis darbas, 3(2), 24-34.

Prakapas, R. (2007). Socialinių darbuotojų santykiais su klientais: vertybinis aspektas. Socialinis darbas, 6(1), 62-67.

Rogers, C. R. (2005). Apie tapima asmeniu: psichoterapeuto požiūris ị psichoterapija. Vilnius: VIA RECTA.

Šatkauskienè, S. (2014). Socialinio darbuotojo ir kliento sąveika vykstant pagalbos procesui: „Pasitikèjimą pirmiausiai reikia igyti“. Socialinis darbas. Patirtis ir metodai, 14(2), 99-119.

Šileika, A., \& Zabarauskaite, R. (2006). Skurdas, jo matavimas ir tendencijos Lietuvoje. Ekonomika, 74, 64-78.

Šliogeris, A. (2011). Transcendencijos tyla. Vilnius: Margi raštai.

Švedaitè-Sakaulauskè, B., Buzaitytè-Kašalynienè, J., \& Gvaldaitè, L. (2014). Socialinis darbas ir galia: teoriniai tyrinëjimų pagrindai. Socialinis darbas. Patirtis ir metodai, 13(1), 9-31.

Taljūnaitè, M. (2004). Pilietybè ir socialinè atskirtis šiuolaikinèje Europoje. Filosofija. Sociologija, 4, 46-49.

The Principle of Respect for Human Dignity: European Commission for Democracy through Law (1998). Science and technique of democracy, 26(18), 43-46.

Urmonienè, M. (2002). Marginalinės grupès - socialinio darbo dalykas. Socialinis darbas, 2(2), 134-140.

Urmonienè, M. (2005). Jaunimo marginalizacija ir resocializacijos galimybès vietos bendruomeneje. Daktaro disertacija. Socialiniai mokslai, sociologija. Kaunas: Kauno technologijos universitetas.

Vaišvila, A. (2004). Žmogaus orumas ir teise i orumq. Žiniasklaida ir asmenybès raida: nepilnamečiu apsauga ir žmogaus orumas. Vilnius: VPU leidykla.

Vaišvila, A. (2005). Žmogaus orumas ir teisè ị orumą teisinio personalizmo požiūriu. Jurisprudencija, 71(63), 49-61.

Venckienè, E. (2005). Žmogaus orumo ir teisès ị orumą sampratų įvairove ir jos kritinè analizè. Jurisprudencija, 77(69), 91-98.

Venckienè, E. (2008). Žmogaus orumas kaip teisinè kategorija. Daktaro disertacija. Vilnius: MRU.

Virbalienè, A. (2006). Paaugliu orumo ugdymasis bendraamžiu grupèse. Daktaro disertacija. Socialiniai mokslai, edukologija. Kaunas: VDU leidykla.

Virbalienė, A., \& Žydžiūnaitè, V. (2010). Paaugliu orumas: mokiniai mokykloje ir asmeninejje aplinkoje. Kaunas: VPU leidykla.

Vorhaus, J. (2015) Giving Voice to Profound Disability: Dignity, Dependence and Human Capabilities. London: Routledge.

Vaicekauskienè, R. (2003). Neįgalių vaikų ugdytojų požiūris ị bendradarbiavimą. Socialinis darbas, 1(3), 57-71. 